\title{
Building Bridges: Cultivating Partnerships between Libraries and Minority Stu- dent Services
}

\author{
By Emily Love, University of Illinois, Urbana-Champaign
}

\begin{abstract}
Research on multiculturalism in libraries focuses primarily on collection development and on the recruitment of minorities to the profession. Although multicultural student outreach is relatively uncommon, it is essential in helping to combat the social, education, technological and financial barriers that leave many minority students at a disadvantage in their transitions from high school to university. A step-by-step approach to cultivating partnerships between the library and multicultural student services is discussed. Potential obstacles such as time constraints, limited resources and student interest are also noted. Ultimately, outreach initiatives produce positive publicity for the library, enrich student learning, and promote the library as a campus leader in the academic process.
\end{abstract}

\section{Introduction}

The period between the late 1980s and the mid 1990s marked a significant growth of research on multiculturalism in libraries. The scholarly works from this period convey research and best practices that discuss multicultural collection development, recruitment and retention of minority librarians, and internships and mentorship programs. Currently, discussions and research on faculty-librarian liaison work dominate library literature; however, not many of these articles approach the array of possibilities that exist for librarians to collaborate with student services programs such as multicultural student centers. In a basic search in Library Information Science Abstracts and Wilson's Library Literature for the terms "information literacy" and "faculty", the result sets reached several hundred. Comparably, several searches in both databases for information literacy and multicultural centers or student services organizations yield only a spare number of titles. Although multicultural library outreach is a chronically under-explored area, the potential and value of the collaborative opportunities are just as important in helping to develop students' critical thinking skills outside the classroom as faculty-library partnerships inside the classroom.

Minority students across the country are more likely to face challenges in accessing information, technologies, and educational opportunities than the white majority. In the year 2000, minorities represented roughly one-third of the projected work force in the United (Norlin and Morris, 1999). The educational barriers and technological divisiveness that minorities encounter combined with the cultural shift in population help to highlight the importance and the necessity for libraries to implement proactive initiatives in reaching out to their under-served constituents. This essay will examine the current literature on multicultural outreach and the array of current multicultural programming across the United States and will discuss potential collaborative partnerships as well as methods on how-to cultivate effective and lasting relationships with student services organizations.

\section{Literature Review}

Prevailing literature on multicultural outreach programming frequently addresses common themes such as the present lack of multicultural outreach initiatives across academic communities, barriers preventing minority student success in their academic studies, and new approaches to multicultural programmatic ventures.

Christopher Hollister (2005) of the University of Buffalo notes that librarians infrequently approach student services groups for library outreach, collaboration, or instruction. In a recent survey of job announcements, Colleen Boff, Carol Singer and Beverly Stearns (2006) highlighted that outreach, as a central 
component of job duties, existed in only a select number of job advertisements. In their study of 115 outreach positions, only seventeen job descriptions addressed outreach in context of multicultural services (outreach to ethnic and racial minority groups). Another study, conducted by Elaina Norlin and Patricia Morris (1999), surveyed over forty directors and staff from various minority cultural centers across the country about library collaboration. The results indicated that eighty-five percent of those surveyed stated that the library initiated no contact with them about their services. Additionally, only fifteen percent stated that "librarians occasionally helped with some form of collection development or cataloging (ibid)." Scott Walter (2005) commented on the fact that academic librarians rarely take advantage of the natural partnerships on campuses. The potential of partnering with a network of student services lies in the communal goal of fostering a campus environment that supports diversity. This latter point helps to illustrate the shared set of fundamental values common to both libraries and student services. Both libraries and student services groups serve to foster learning outside of the classroom and to instill life-long critical thinking skills in students, which demonstrates a foundation for the cultivation of new partnerships.

Although multicultural student outreach is relatively uncommon, it is nevertheless essential in helping to combat the social, educational, technological, institutional, and financial barriers that leave many minority students at a great disadvantage in their transitions from high school to university (Norlin and Morris, 1999, Walter, 2005, Simmons-Welburn and Welburn, 2001). Moreover, once enrolled in university, a striking number of minority students, particularly African-American and Hispanic students, fail to stay on course to graduation. The retention rates of minority students across the United States are staggeringly uneven between white students and minority students. In Retaining African Americans in Higher Education that Hispanics, Lee Jones $(2001,7)$ wrote that in 1997African Americans and Native Americans trailed behind the graduation rates of white and Asian-American students. Across the nation, the average retention rates of white students stood at fifty-eight percent, whereas for African-American students, the retention rate was eighteen percent lower, at forty percent. Brent Mallinckrodt's and William E. Sedlacek's 2003 empirical study developed evidence demonstrating that academic library use made a positive impact on the retention rates of minority students. They noted the undergraduate library specifically for its positive impact on retention rates of African American undergraduate students. Multicultural outreach in an academic library environment may not necessarily produce improved retention rates of minority students; however, the combination of the disadvantages and barriers that so many under-represented groups on campuses currently face should encourage more libraries to implement multicultural programming as a method of dealing with these discouraging statistics.

Although multicultural outreach initiatives are currently under-represented in the literature, an increasing number of schools are beginning to undertake innovative and dynamic collaborative initiatives. In an overview of the available literature on student services collaborations, more libraries are beginning to reach out to student services groups such as the campus academic writing centers and career centers (Kraemer Keyse and Lombardo, 2003; Hollister, 2005). In terms of specific multicultural services, fewer libraries are taking an active outreach role; however, current outreach programs implemented by universities libraries are often highly dynamic and innovative. Within the range of multicultural services on campus, the Office of Minority Student Affairs (OMSA) is an ideal and valuable first place to begin collaborating (Simmons- Welburn and Welburn, 2001; Harrell and Menon, 2002; Scott, 2005). The campus Office of Minority Student Affairs leads a versatile selection of academic programs such as the federally funded McNairs Scholars Program and Summer Bridge Program, summer and fall orientation programs, peer mentoring and study skills workshops. Libraries interested in partnering with these centers can find simple methods of collaboration by integrating a library component such as research guides, web tools, or library instruction into a pre-existing program. Another promising area of collaboration, although less common, lies in international student engagement, offered through either the Office of International Services or the Study Abroad Office. Finally, many universities across the United States promote their cultural centers to minority students as a place to study and to relax. Many student cultural centers lead weekly academic and cultural workshops, making it another ideal avenue for collaboration and outreach (Simmons-Welburn and Welburn, 2001; Walter, 2005; Norlin and Morris, 1999). With so many student services currently lacking in available funds to offer needed academic programming, through joint collaboration, libraries can help students address their academic needs in a more accessible manner. 


\section{Opportunity Analysis at the University of Illinois}

Established in 1867, the University of Illinois currently enrolls over 42,000 students from all fifty states in its sixteen colleges. The student population consists of 6.1 percent African-Americans, 5.9 percent Latinos, 10.68 percent Asian-Americans, 0.29 percent Native-Americans and 12.36 percent international students. The current administration supports a wide range of student services, many of which cater to students of multicultural and international backgrounds. For instance, the University supports four cultural centers on campus (for African-American, Hispanic, Asian-American and Native-American students); an Office of Minority Student Affairs; a Study Abroad Office; an International Students and Scholars Office; an Intensive English Institute; an Office of Disabilities; a Gay, Lesbian, Bisexual and Transgender Office; hundreds of student-run organizations that support diversity and international issues, and several dozen diversity initiatives and summer programs instigated by many of the schools and departments. The campus is actively demonstrating its commitment to diversity and ensuring that they bring diversity to the forefront. In 2002, the Chancellor's Office enacted a campus-wide diversity committee. Soon after, the University Library followed suit, creating its own diversity committee, which aimed to foster an inclusive working environment for faculty, staff, students, and the community. The campus also finally retired its racially charged sporting mascot, the Chief, which helped to produce a more open and inclusive environment across the campus community. The combination of the campus' diverse student body and its wide range of campus diversity programs help to lay a solid foundation for a dynamic library multicultural outreach program.

\section{Cultivating Partnerships on Campus: A Step-by-Step Guide}

Many students regardless of cultural or ethnic background often profess feelings of intimidation or nervousness when approaching academic libraries and librarians (Norlin and Morris, 1999). Student reluctance to use the library's facilities combined with the historic lack of multicultural outreach provides an impetus for librarians to bring the library outside the confines of the library walls and into the student services environment. Every campus, large or small, lends institutional and financial support programs to its students, although many of these programs are often harmed by a shortage of staff or by financial strains. The library, which acts in a leading role contributing to student's academic success and as an integral institution on campus, is well positioned to fill some of the needs of other campus units, to reach out to more students, and to promote itself as a vital part of the university campus. Venturing into any new program requires time, organization and motivation. The following steps, which have been adapted from a study by Elaina Norlin and Patricia Morris, aim to help librarians, unfamiliar with outreach, to the endless list of collaborative possibilities that exist beyond the walls of the library.

Phase 1: Identify potential partnerships.

Investigate the types of student services groups or multicultural services available on campus. Asking questions about the library's needs and goals will help to identify a strong starting point. For example, what types of collaborations could the library benefit from? What can the library offer in terms of available resources, staff time or physical space? What programs exist on campus that students utilize but have been left under-funded or understaffed? Does the campus have an Office for Minority Student Affairs? Does the campus support cultural centers or support services for students with disabilities? Appendix I examines some of the partnerships that were identified and the resulting programs cultivated between the University of Illinois Library and student services for multicultural and minority students.

Phase 2. Identify the needs of student services groups.

Once you find an organization that the library is interested in contacting, then begin gathering information about the center's history, strategic goals, mission statement, staffing, facilities, wireless connections, website, and most importantly, the programs available to students and the potential needs of the organization. For example, does the center offer study skills programs or peer mentoring programs? Do they have collection needs? Do they have a library link on the office's website? What services do they lack, and what type of support could they use in the future? Is there potential to collaborate on an exhibit or display? Has this organization collaborated with other units on campus in the past or present? What types of services does the library offer that can fill their needs? The goal here is to examine the center's goals and to integrate the library's services into their goals. Ultimately, the answers to these questions will gen- 
erate a powerful list of potential collaborative opportunities between the library and the chosen office on campus.

\section{Phase 3. Make a connection.}

Locate the contact information of the outreach coordinator or the director of the specified organization. For the preliminary contact, it may prove preferable to send an e-mail to introduce yourself instead of a phone call so that you can succinctly outline some of your investigations, highlighting the library's current services, and you can then suggest new ways to collaborate. After you make the connection, you will follow up by suggesting an appropriate time and place to meet. Meeting prior to holidays and weekends may not be the ideal time for an initial meeting because staff may put aside projects or forget about them after the weekend or holiday.

Phase 4. Cultivate the collaboration.

Once both parties agree to an appropriate time and place to convene, you can then begin to discuss your ideas, and approach the coordinator or director about their ideas or suggestions for program collaboration. Sometimes small talk helps to alleviate awkward moments, and it also creates a personal connection between parties, which can ultimately foster a more dynamic partnership. Once an active discussion develops, both parties should agree on a starting point and assign duties. Both parties should be willing to commit their own time and resources in order to ensure an effective program. Starting with a small project may also prove helpful in the initial phase of the partnership, as it can lead to bigger and more engaging programs. A simple way to plant the foundation for a lasting partnership may be to attend to their current needs, as it opens doors to expand programming in the future. Solidifying the meeting with a follow-up email or phone call, thanking the individual for their time and ideas, will help to ensure a positive foundation for future correspondence.

Phase 5. Ensure a lasting partnership.

The collaboration process with professional staff members in lieu of faculty can potentially hinder the long term success of the collaboration unless the library takes certain precautions in advance. In a rapidly changing work environment, many professional staff change job titles, shift positions, and ultimately start new careers. Job turnover can end ties between individuals, but it should not terminate the partnerships established between units. Leaving a file or paper trail of past correspondence will ensure that successful incumbents learn about current and evolving collaborations and projects. Additionally, the integration of the partnership onto both the library's website and the center's website will produce evidence of a solid partnership. Finally, maintaining regular correspondence during the ensuing months will solidify continued collaboration and may even lead into future projects as well.

Phase 6. Ensure an effective partnership through publicity.

Promoting new programs such as an information literacy workshop will take time and creative tools in order to attract sizeable groups of students. Publicity can be achieved through simple or complex methods. For instance, the library and the center may consider publicizing the new service or collaborative initiative through their respective websites. Most student services centers maintain a listserv that circulates to a large number of students. Web publicity through listservs and websites reach an optimal number of students. Additionally, flyers and posters may catch the eye of those passing by the center or the library. Effective publicity should include essential information such as dates, times, locations and an enticing, brief description of the upcoming program.

Phase 7: Evaluate and assess the partnership.

The final stage in the cultivation of new collaborations should include an evaluation of the program in the form of a follow-up survey, focus-group, report, or meeting with either participants or staff. The assessment should include opinions pertaining to the progress, successes, problems and opportunities of the past initiative or collaboration. The information obtained from the assessment will enable both parties to refine current programs and to move forward in developing and implementing more proactive programming in the future.

\section{Obstacles}


Any new collaboration encounters problems and obstacles that may prevent future developments. For instance, lack of time poses a significant barrier to the progress of any new initiative. For both institutions, individuals must commit their own time in an age where administrative expectations run high and financial sources run low. As a direct consequence, the availability of staff time to coordinate the planning and implementation of new programs suffers. Problems pertaining to time are easily surmountable. Planning to collaborate on smaller projects prior to the development of more large-scale programs establishes a rapport between both parties while maintaining a smaller workload. A limited partnership, while still remaining strong, will set the foundation for a lasting relationship and for new collaborative opportunities.

Limited resources can potentially impede the development of certain programs. If the desired collaboration consists of a one-time information literacy workshop at the cultural center, it is important to find out if the center is equipped with computer facilities and internet or wireless connections. In addition to physical resources, staffing resources may also negatively affect the success of a new program. For instance, some staff at the centers may not care to acquire new duties, or they simply might not have the time needed to devote to a new project. Additionally, when staff members leave the centers, they also end the established partnership, requiring more time to cultivate the partnership anew. This latter point exemplifies the need to embed the history of the partnership into the records in both the center and the library, which can be achieved through archived electronic correspondence and through website publicity of the program.

The lack of student interest can also negatively affect the future of the collaboration. If, for example, the partners decide to develop a library skills workshop for the cultural center, regardless of location, students in general demonstrate an underwhelming interest in learning library skills. Initially, as with many new academic programs, student interest may be low; however, the combination of effective publicity and time can help raise awareness about new programs.

\section{Benefits of Outreach}

Collaborations between libraries and student services produce a range of benefits not only for the library and the student services, but also for administrators, students, and the community. The cultivation of dynamic partnerships changes the role of libraries from passive to proactive players in the academic process (Hollister, 2005). Faculty historically demonstrate an assumption that library outreach should consist of collection development and reference services. The early 1990s witnessed a surge in library literature addressing the subject of multicultural outreach. As more authors write about multicultural outreach programming, it demonstrates the growing importance of these initiatives.

Library outreach to student services groups who provide academic programs to minority students can increase students' likelihood to visit the library and to approach a librarian for assistance with research papers and coursework. In a recent study in C@RL News, it stated that collaboration leads to the enrichment of student learning (June, 2005). Additionally, initial contact and small-scale project coordination between libraries and student services create trust and allied partners across campus, which opens doors for new program development and establish valued support for preexisting ones. Outreach beyond the classroom helps to reach students outside the general classroom, ingraining lifelong critical thinking skills.

Additionally, collaboration between libraries and multicultural student services garners positive publicity not only for the library but for the university as well. Collaboration and outreach demonstrates the library's commitment to campus diversity initiatives, and it leads to increased cultural awareness among faculty, staff and students, fostering a welcoming and inclusive campus environment. For the library, these collaborations demonstrate the commitment to diversity, which may earn the library a more active role in campus diversity committees and discussions. For the individual librarian, these collaborations can also translate into potential publications and recognition at the state or national level. 


\section{Appendix I: Multicultural Outreach at the University of Illinois}

\section{Office of Minority Student Affairs}

Many larger universities across the United States support an office for minority student affairs (OMSA), which is responsible for the provision of leadership in developing, implementing and coordinating student support services. These offices also design activities to assist underrepresented students' personal development, and offers academic workshops until students graduate. The library at the University of Illinois recently initiated a collaborative partnership with the OMSA. The library reviewed the OMSA's website, the goals and mission statement and accordingly planned a program that could easily be integrated into their current academic and study skills programming. After several initial meetings and conversations, the outreach coordinators from the library and the OMSA successfully incorporated a weekly library research tutorial into the office's weekly study skills program for a maximum of three students per week. To promote this workshop, both the OMSA and the library list the times and location of the library research session on their respective websites.

\section{McNairs Scholars Program}

The McNairs Scholar Program is a federally funded program offered through the Office of Minority Student Access that prepares participants for doctoral studies through research and other scholarly activities. Participants generally come from disadvantaged backgrounds, and display strong academic skills. The goal of this program is to introduce senior level undergraduate students from under-represented groups to graduate school and Ph.D. programs. At the University of Illinois, the library contacted the Office of Minority Student Affairs about integrating a library component into the summer-long program. After several years of collaboration with the McNairs Scholars Program, the library continues to develop programming for the orientation section of the program, incorporating a tour of the Main Library, in addition to a onetime information literacy workshop. Throughout the summer, a librarian also leads summer office hours where students can drop in with any research problems.

\section{Cultural Centers}

The University of Illinois houses four cultural centers: African-American, Hispanic, Native-American and Asian-American. These centers offer students a range of support services including mentorship programs, tutoring, computer labs, study and social space, weekly lectures and cultural programs. The Cultural Centers, however, offer students a comfortable and welcoming climate, which laid the foundation for a new avenue for outreach. The library contacts the Cultural Centers each semester prior to the mid-term season to schedule a one-time library research session. In these sessions, a librarian introduces students to the library's print and electronic resources and effective search strategies of the online catalog and popular databases and indexes. These sessions can unfold into a myriad of positive outcomes and additional programs. For instance, close connections with minority students through tutoring can develop into a mentorship relationship. Working one-on-one with minority students at the centers, the librarian can impart personal experiences from the profession and expose these students to an unconsidered career. Additionally, the connections formed with the staff liaisons at the cultural centers may yield new collaborative projects such as an exhibit or library research workshop for the center's staff.

\section{Study Abroad Office}

Each year almost a quarter of a million students across the United States choose to study abroad for a year in a foreign country. The Study Abroad Office at the University of Illinois sends almost two thousand students to foreign countries each year, which represents a significant number of the undergraduate population. The Study Abroad Office offers students access to a small collection of travel books that it stores in its main office. However, after an initial meeting with the office's outreach coordinator, it became clear that the library could collaborate in several ways. Every year the Study Abroad Office organizes an information session for students, for which they assemble packages of information for students intending on traveling abroad. After brief discussions, it was decided that the library would prepare resource guides with lists of films, literature, music and current periodicals, which will help to enrich students about the foreign country and culture prior to partnership. 


\section{Office of International Students and Scholars}

The campus office for international students and scholars states that it "strives to create an environment that allows for successful educational and personal experiences through orientation, advising, programs and outreach." The library and the Office of International Students and Scholars had not engaged in collaborations until recently, when the library held its annual multilingual library tours. For the event, the library contacted the Office of International Students and Scholars, who offered to help promote the event by contacting over fivethousand students over its listserv, which ultimately lead to a highly successful event.

\section{References}

Big 12 Plus Libraries Consortium Diversity Conference, \& Lee-Smeltzer, K.-H. (Ed.). (2001). Diversity now: People, collections, and services in academic libraries. New York: Haworth Press.

Boff, C., Singer, C., \& Beverly, S. (2006). Reaching out to underserved: More than thirty years of outreach job ads. The Journal of Academic Librarianship, 32(2), 137-147.

Dewey B. I., \& Parham L. (Eds.). (2006). Achieving diversity: A how-to-do-it manual for librarians. New York: Neal-Schuman.

Harrell, M., \& Menon, V. (2002). Servicing diverse library users: The multicultural studies librarian at an urban research university. Paper presented at the Diversity in Academic Libraries Conference, lowa City.

Hill, K. (Ed.). (1994). Diversity and multiculturalism in libraries. Greenwich, CT: Jai Press.

Hollister, C. (2005). Bringing information literacy to career services. Reference Services Review, 33(1), 104-111.

Holmes, B., \& Lichtenstein, A. (2003). Minority student success: Librarians as partners. College \& Research Libraries News, 59(7), 496-498.

Kraemer, E., W., Keyse, D. J., \& Lombardo, S. V. (2003). Beyond these walls: Building a library outreach program at Oakland university. The Reference Librarian, 82, 5-17.

Metoyer, C. A. (2000). Missing links in reaching culturally diverse students in academic libraries. The Journal of Academic Librarianship, 26(3), 157-158.

Norlin, E., \& Morris, P. (1999). Developing proactive partnerships: Minority cultural centers. The Reference Librarian, 67/68, 147-160.

Osborne, R. (2004). From outreach to equity: Innovative models of library policy and practice. Chicago: American Library Association.

Curry D. A., Griswold, S., B. \& Martin L. M. (Eds.). (1994). Racial and ethnic diversity in academic libraries: Multicultural Issues. New York: Haworth Press.

Ransom, C. The Diversity Librarian.

Riggs D. E., \& Tarin P. A. (Eds.). (1994). Cultural diversity in libraries. New York: Neal-Schuman.

Walter, S. (2005). Moving beyond collections: Academic library outreach to multicultural student centers. Reference Services Review, 33(4), 438-458.

Walter, S. (2005). Instructional outreach and campus diversity: Building partnerships with multicultural student services. Paper presented at the annual meeting of the Academic Library Association of Ohio, Columbus.

Simmons-Welburn, J., \& Welburn, W. C. (2001). People: Recruitment and retention. Journal of Library Administration, 33(1/2), 5-19.

Emily Love, Assistant Professor of Library Administration, is the Outreach Librarian for Multicultural Services for the Undergraduate Library at the University of Illinois, Urbana-Champaign. Email:

elove@uiuc.edu 